Natalia PIECHOTA

Uniwersytet Ekonomiczny w Poznaniu

\title{
ZARYS ZAŁOŻEŃ METODOLOGICZNYCH BADAŃ NAD WPEYWEM WYDARZEŃ SPORTOWYCH I TURYSTYKI BIZNESOWEJ NA KONKURENCYJNOŚĆ MIAST
}

\section{Wstęp}

Zachodzące procesy globalizacyjne skutkują nasilaniem się konkurencji nie tylko na poziomie przedsiębiorstw, lecz także państw i regionów. Zjawisko to dotyczy m.in. turystyki. Regiony rywalizują o turystów nie tylko z sąsiednimi obszarami, ale nawet $\mathrm{z}$ tymi, które leżą po drugiej stronie globu (BUHALIS, EGGER, red. 2008). Proces ten wymaga identyfikacji mocnych stron regionu i wypracowania przewagi konkurencyjnej, umożliwiającej wyróżnienie obszaru spośród pozostałych. Dążenie do rozwoju turystyki ma o tyle duże znaczenie, że nawet jeżeli nie jest ona dominującym sektorem lokalnej gospodarki, to jej rozwój generuje wiele pozytywnych efektów, zarówno gospodarczych, jak i społecznych (GOELDNER, RITCHIE 2003).

Konkurowanie na arenie międzynarodowej w dużym stopniu dotyczy miast, które rywalizują nie tylko o turystów, ale też o inwestorów, przedsiębiorców i nowych rezydentów. Mogą w tym pomóc wydarzenia sportowe oraz formy aktywności z zakresu turystyki biznesowej, które przyczyniają się do tworzenia przyjaznego otoczenia zarówno dla mieszkańców, jak i dla biznesu. Dlatego obecnie wiele miast zabiega o organizację dużych imprez sportowych (GETZ 2003) lub międzynarodowych spotkań stowarzyszeń czy mniejszych „eventów”, a wręcz część jednostek przestrzennych opiera budo- 
wanie swojej przewagi konkurencyjnej na tego typu segmentach (ZMYŚLONY, PIECHOTA 2014).

Opracowanie ma charakter koncepcyjny, a w projekcie nacisk zostanie położony na wpływ wydarzeń sportowych i turystyki biznesowej na konkurencyjność miast. W pierwszej kolejności omówiono znaczenie imprez sportowych oraz turystyki biznesowej dla miast. Następnie wskazano ich miejsce $\mathrm{w}$ dotychczasowych modelach konkurencyjności regionów turystycznych. Całość zamyka prezentacja najważniejszych założeń badań: problemu badawczego, celu, hipotezy, zakresów badawczych oraz zarys metodyczny. Ze względu na fakt, że praca stanowi koncepcję rozprawy doktorskiej, nie zawarto w niej wyników badań ani rezultatów poznawczych z nich wynikających.

\section{Znaczenie wydarzeń sportowych i turystyki biznesowej dla miast}

Wydarzenia sportowe stanowią jedną $\mathrm{z}$ wielu grup różnorodnych wydarzeń (GETZ 2008), a w tym opracowaniu zaliczono do nich tylko imprezy obejmujące zawody znajdujące się w kalendarzu rozgrywek określonej dyscypliny, w ramach których rywalizują ze sobą profesjonaliści lub amatorzy. Pominięto tym samym "eventy" o charakterze czysto rekreacyjnym. Podobnie jak inne rodzaje wydarzeń, mogą one generować wiele efektów, które dotyczą nie tylko ich organizatora, lecz również regionu, w którym się odbywają. J. ALLEN, W. O'TOOLE, I. MCDONNELL I R. HARRIS (2002) stwierdzili, że można wyodrębnić turystyczne, ekonomiczne, społeczne, ekologiczne i polityczne konsekwencje „eventów”.

Pod względem turystycznym istotne jest to, że wydarzenia wchodzą w skład lokalnego produktu turystycznego (SWARBROOKE 2005), będąc równocześnie produktem i atrakcją samą w sobie (WANAGOS 2010). Stanowią także główny motyw podróży dla wielu osób (NAWROT, ZMYŚLONY 2009). Dla turystów przyjeżdżających do miasta specjalnie na określoną imprezę koszt udziału w niej będzie istotnym wydatkiem w łącznej sumie kosztów poniesionych w związku z wyjazdem. Należy też zaznaczyć, że kibice sportowi są istotną kategorią konsumentów turystycznych (HADZIK, SZROMEK, TOMIK 2012). Ponadto wydarzenia wzbogacają lokalny produkt turystyczny i tym samym pomagają $\mathrm{w}$ zdobyciu nowych rynków oraz segmentów tury- 
stów, a także w przeciwdziałaniu sezonowości (GOELDNER, RITCHIE 2003). Równocześnie wpływają też na wizerunek danego miejsca (Piotrowski 2012) i atmosferę w nim panującą. Z tych powodów władze lokalne często zabiegają o możliwość organizacji imprez, szczególnie o międzynarodowej randze (GETZ 2003).

Napływ turystów oddziałuje na stan lokalnej gospodarki przyczyniając się nie tylko do rozwoju przedsiębiorstw turystycznych, lecz także innych niezwiązanych bezpośrednio z obsługą podróżnych (LITVIN 2013). Z kolei przynajmniej czasowe zwiększenie sprzedaży i zatrudnienia wpływa dodatnio na PKB regionu, a inwestycje poczynione $w$ ramach przygotowań do organizacji wydarzeń nie dość, że aktywizują gospodarkę, to jeszcze później mogą służyć także mieszkańcom (STERKEN 2006). Rezydenci też odnoszą korzyści z tytułu odbywania się wydarzenia poprzez poszerzanie swoich horyzontów oraz niejednokrotnie odczuwanie dumy z przynależności do określonej społeczności (ALLEN, O’TOOLE, MCDONNELL, HARRIS 2002). Imprezy sportowe mogą również stanowić okazję do promowania postaw proekologicznych (COLLINS, JONES, MUNDAY 2009).

Oprócz licznych pozytywnych skutków, wydarzenia generują wiele negatywnych konsekwencji. $Z$ jednej strony przyciągają one turystów, ale równocześnie część $\mathrm{z}$ nich i tak przyjechałaby w określone miejsce, więc nie następuje dodatkowy impuls dla gospodarki, a jedynie przesunięcie w strukturze konsumpcji (LITVIN 2013). Inni mogą zrezygnować z wyjazdu lub odłożyć go w czasie, żeby uniknąć tłoku (HERNÁNDEZ-MARTín 2007). Zaburzony zostaje także codzienny rytm funkcjonowania mieszkańców i przedsiębiorców (WOOD 2005). Dodatkowo, przez liczne utrudnienia: hałas, korki, wzrost przestępczości itp., a także degradację środowiska, powstaje niechęć rezydentów do turystów (ALlen, O'TOOLE, MCDONNELl, HARRIS 2002, COLLINS, JONES, MUNDAY 2009). Każdy z efektów (zarówno pozytywny, jak i negatywny) może zostać wykorzystany podczas sporów przez różne partie i stronnictwa polityczne (ALLEN, O'TOOLE, MCDONNELL, HARRIS 2002).

Wiele konsekwencji dla określonego obszaru generuje również turystyka biznesowa, rozumiana jako podróże służbowe związane najczęściej z wykonywaniem nierutynowych zajęć służbowych, odbywane grupowo i w przypadku których istnieje pewna dowolność wyboru miejsca wyjazdu (DAVIDSON, COPE 2003). Zalicza się do niej takie segmenty, jak: wystawy/targi, turystyka korporacyjna, podróże motywacyjne i spotkania. Zbliżonym określeniem stosowanym zamiennie w stosunku do turystyki biznesowej jest przemysł MICE, czyli akronim od słów: meetings (spotkania), incentives 
(podróże motywacyjne), conferences (konferencje) i exhibitions (wystawy) (DAVIDSON, COPE 2003).

Miasta są głównymi miejscami koncentracji biznesowej, dlatego w nich rozwija się turystyka biznesowa. W wielu przypadkach jest ona źródłem przewagi konkurencyjnej określonej jednostki przestrzennej. To dochodowy segment turystyki, ponieważ przeciętne wydatki turystów biznesowych z reguły są wyższe od kosztów ponoszonych przez osoby podróżujące w celach wypoczynkowych. Ponadto wyjazdy w ramach tej kategorii w mniejszym zakresie podlegają wahaniom sezonowym i jedynie nieznacznie zależą od czynników atmosferycznych (poza podróżami motywacyjnymi) (DAVIDSON, COPE 2003).

Turystyka biznesowa w większym stopniu zasila gospodarkę nie tylko ze względu na wyższy przeciętny poziom wydatków podróżujących, lecz również z powodu dużego zaangażowania usług pomocniczych. Wypracowanie pozytywnego wizerunku miejsca sprzyjającego biznesowi może przyczyniać się ponadto do napływu zagranicznych inwestycji. Dodatkowym zyskiem jest fakt, że zadowoleni goście nie dość, że prawdopodobnie ponownie odwiedzą określone miasto, np. w wolnym czasie, to również często polecą je zarówno do prowadzenia interesów, jak i na wypoczynek. Poza tym, analizując konsekwencje pozaekonomiczne, należy zwrócić uwagę, że turystyka biznesowa $\mathrm{w}$ mniejszym stopniu przyczynia się do degradacji środowiska, ponieważ odbywa się głównie na obszarach zurbanizowanych i nie jest tak skoncentrowana geograficznie jak turystyka wypoczynkowa. Opisywany segment wiąże się jednak również niejednokrotnie z koniecznością ponoszenia wysokich kosztów na infrastrukturę oraz kosztów społecznych, w szczególności w przypadku organizowania dużych wydarzeń (DAVIDSON, COPE 2003).

\section{Współistnienie wydarzeń sportowych i turystyki biznesowej oraz ich wpływ na konkurencyjność miast}

Wielu autorów (m.in. DWYER, FORSYT, RAO 2000, POON 1993, PORTER 1990, RITCHIE, CROUCH 2000) próbowało określić czynniki determinujące konkurencyjność regionu turystycznego. Zaowocowało to powstaniem różnorodnych modeli wyjaśniających, dlaczego pewne miejsca osiągają przewagę konkurencyjną, a inne są mniej skuteczne w rywalizacji o turystów. Źródeł 
przewagi dopatrywano się m.in. w oferowaniu konkurencyjnych cen (DWYER, FORSYT, RAO 2000), w lokalnych atrakcjach (RITCHIE, CROUCH 2000) i w gospodarce turystycznej (PORTER 1990), a także w wykorzystaniu innowacji (POON 1993) oraz pozytywnego wizerunku regionu (RITCHIE, CROUCH 2000)1. W każdym z wymienionych czynników istotną rolę mogą odgrywać wydarzenia o charakterze sportowym oraz turystyka biznesowa, a tym samym mogą przyczynić się do wypracowania przewagi konkurencyjnej regionu.

Jeżeli każdy z tych dwóch motywów podróży osobno może oddziaływać na konkurencyjność, to kolejną szansę może stanowić ich połączenie. Biznes i sport są ze sobą mocno powiązane, w decydującej mierze poprzez sponsoring. Istnieje jednak również wiele obszarów wspólnych dla segmentów, jakimi są wydarzenia sportowe i turystyka biznesowa. Dla osób interesujących się sportem najbardziej oczywistym i prawdopodobnie najczęściej spotykanym przykładem na potwierdzenie powyższej tezy jest organizacja spotkań zaliczanych do turystyki korporacyjnej podczas wydarzeń sportowych. Szczególnie w trakcie prestiżowych zawodów w ramach dyscyplin, uważanych za elitarne lub bardzo popularne biznesmeni wykorzystują okazję do nawiązania kontaktów z potencjalnymi lub wzmocnienia relacji z najważniejszymi kontrahentami, a także wypracowania pozytywnego wizerunku firmy i wyróżnienia najbardziej zaangażowanych pracowników (DAVIDSON, COPE 2003). Podczas imprez sportowych przedsiębiorcy mogą również zaprezentować swoje nowe produkty, a ponadto „eventy” takie stanowią okazję do organizacji innych wydarzeń.

Wydarzenia sportowe i turystykę biznesową łączy również najczęściej ich lokalizacja, czyli miasta, w których najchętniej organizowane są imprezy sportowe i które stanowią miejsce koncentracji biznesowej. Dlatego istnieje możliwość, że w wyniku połączenia wymienionych dwóch elementów w określonym mieście wystąpią efekty generowane przez nie samodzielnie oraz że przynajmniej częściowo zostaną zniwelowane skutki negatywne, a wzmocnione zostaną konsekwencje pozytywne.

W przypadku wydarzeń sportowych częstym problemem jest występowanie tzw. efektu wypierania, czyli sytuacji, w której turyści podróżujący w celach innych niż uczestnictwo w imprezie powstrzymują się od przyjazdu do miasta w trakcie jej trwania głównie dlatego, żeby uniknąć łłoku

\footnotetext{
${ }^{1}$ Znaczenie wizerunku podkreślano także w publikacjach związanych pośrednio z tematyką turystycznej konkurencyjności regionu (zob. VANHOVE 2005 cytujący: Bordas 1994).
} 
(HODUR, LEISTRITZ 2006). W pewnym stopniu niwelowanie tego zjawiska jest możliwe poprzez powiązanie udziału $\mathrm{w}$ wydarzeniu $\mathrm{z}$ motywem biznesowym. Dodatkowo imprezy sportowe odbywają się najczęściej latem, kiedy można się spodziewać dobrych warunków pogodowych, czyli poza sezonem w turystyce biznesowej.

Nie bez znaczenia są również kwestie ekonomiczne. Ze względu na wydłużenie sezonu w turystyce biznesowej oraz pozyskanie „dodatkowego" segmentu klientów przez organizatorów imprez sportowych przedsiębiorcy należący do obu branż mogą uzyskiwać wyższe przychody. Ponadto biznesmeni zyskują nowy kanał komunikacyjny w relacjach $\mathrm{z}$ konsumentami i partnerami, a organizatorzy - źródło finansowania wydarzenia. Pojawienie się kolejnego segmentu turystów (biznesowych) powinno natomiast zainicjować działanie mechanizmów mnożnikowych.

\section{Rozważania nad założeniami metodologicznymi badań dotyczących wpływu wydarzeń sportowych i turystyki biznesowej na konkurencyjność miast}

Ze względu na znaczenie wydarzeń sportowych i turystyki biznesowej, a także na ich potencjał w zakresie oddziaływania na konkurencyjność miast postawiono następujące pytanie, będące problemem badawczym przygotowywanej rozprawy doktorskiej: czy wydarzenia sportowe i turystyka biznesowa generują efekty synergiczne dla konkurencyjności miast? Głównym celem projektu badawczego będzie więc określenie konsekwencji organizacji wydarzeń sportowych i rozwijania turystyki biznesowej, mających wpływ na konkurencyjność miast oraz identyfikacja czynników oddziałujących na wielkość generowanych skutków. Pomoże to w ustaleniu tego, czy połączenie omawianych dwóch branż spowoduje powstanie dodatkowych efektów, które nie występują, gdy są one rozwijane oddzielnie?

Do osiągnięcia celu głównego przyczyni się realizacja trzech celów szczegółowych. Pierwszym z nich jest ustalenie znaczenia wydarzeń sportowych i turystyki biznesowej w modelach konkurencyjności regionów turystycznych. Dzięki temu zostanie określony potencjał obu branż w zakresie podnoszenia konkurencyjności miast, a także będzie możliwe osiągnięcie drugiego celu szczegółowego, którym jest stworzenie teoretycznego modelu oddziaływania wydarzeń sportowych i turystyki biznesowej na konku- 
rencyjność miast. Wymiar praktyczny rozprawy zawiera się $\mathrm{w}$ trzecim celu, czyli określeniu metod i/lub narzędzi dla władz lokalnych, służących ocenie wydarzeń sportowych pod względem ich wpływu na kształtowanie turystycznego potencjału konkurencyjnego miast.

Główną hipotezą rozprawy jest założenie, że wydarzenia sportowe i turystyka biznesowa mogą generować efekty synergiczne w zakresie zwiększania konkurencyjności miast, przy czym w większym stopniu turystyka biznesowa będzie wzmacniać konsekwencje związane $\mathrm{z}$ organizacją imprez sportowych. Hipoteza ta zostanie zweryfikowana podczas badań, których podmiotem będą organizatorzy "eventów” sportowych, a przedmiotem efekty wynikające z przygotowania i realizacji wydarzenia. Zakres czasowy i przestrzenny zostanie doprecyzowany po przeprowadzeniu szczegółowych studiów literaturowych.

Na część metodyczną projektu złożą się dwa elementy: diagnoza tego, $\mathrm{w}$ jakim stopniu wydarzenia sportowe łączą się z turystyką biznesową oraz analiza efektów generowanych przez te dwa czynniki na przykładzie wybranych przypadków. Pierwsza część pomoże w ustaleniu stanu faktycznego oraz skali występowania zjawiska, które dotąd nie było przedmiotem zainteresowania badaczy. W tym celu zostanie przeanalizowana oferta określonych wydarzeń sportowych pod kątem usług i produktów skierowanych do turystów biznesowych. Z kolei dzięki szczegółowemu zbadaniu skutków odbywania się określonych imprez możliwa będzie identyfikacja konsekwencji, które pojawiają się dopiero w wyniku połączenia wydarzeń sportowych i turystyki biznesowej, a także wskazanie, które z nich oraz w jakim stopniu wpływają na konkurencyjność miast. Analiza ta będzie możliwa po przeprowadzeniu pogłębionych wywiadów $\mathrm{z}$ organizatorami wydarzeń sportowych.

\section{Podsumowanie}

Wydaje się, że realizacja powyższego projektu badawczego powinna mieć istotny wkład w badania nad czynnikami warunkującymi konkurencyjność miast oraz nad pomiarem i oceną efektów imprez sportowych i turystyki biznesowej. Szczególnie ciekawe mogą okazać się ujawnione konsekwencje połączenia wymienionych dwóch motywów podróżowania do miasta, dotąd pomijane w literaturze. Jednak już samo szacowanie wpływu wydarzeń jest 
zadaniem złożonym, a stosowane $\mathrm{w}$ tym celu metody naznaczone są licznymi ograniczeniami i wiele $\mathrm{z}$ nich nie uwzględnia aspektów pozaekonomicznych (zob. DAVIES, COLEMAN, RAMCHANDANI 2013, HODUR, LEISTRITZ 2006, MORGAN, CONDLIFFE 2006, PAWLICZ 2012). Ponadto niemożliwe jest przeprowadzenie badania na wszystkich istniejących imprezach sportowych, w związku z czym konieczny będzie odpowiedni dobór kryteriów zawężenia próby badawczej, tak aby uzyskane wyniki były reprezentatywne. Z kolei największą trudność może sprawić proces gromadzenia informacji od organizatorów imprez, ponieważ mogą oni nie zechcieć udostępnić szczegółowych danych finansowych do analiz w obawie przed złamaniem tajemnicy handlowej. Mimo spodziewanych trudności problematyka koegzystencji wydarzeń sportowych i turystyki biznesowej oraz jej wpływu na konkurencyjność miast powinna być podejmowana również $\mathrm{w}$ kolejnych projektach.

\section{Bibliografia}

Allen J., O'ToOle W., McDonnell I., Harris R., 2002, Festival and Special Event Management, John Wiley \& Sons Australia Ltd, Sydney.

BuHAlis D., EgGer R. (red.), 2008, eTourism Case Studies. Management and Marketing Issues, Elsevier, Oxford.

COllins A., JONES C., Munday M., 2009, Assessing the environmental impacts of mega sporting events: Two options?, „Tourism Management”, 30(6), s. 828-837.

DAVIDSON R., COPE B., 2003, Turystyka biznesowa. Konferencje, podróże motywacyjne, wystawy, turystyka korporacyjna. Polska Organizacja Turystyczna, Warszawa.

DAVIES L., COLEMAN R., RAMCHANDANI G., 2013, Evaluating event economic impact: rigour versus reality? International „Journal of Event and Festival Management”, 4(1), s. 31-42.

DWYER L., FORSYT P., RAO P., 2000, The price competitiveness of travel and tourism: a comparison of 19 destinations, ,Tourism Management”, 21.

GETZ D., 2003, Bidding on events, ,Journal of Convention \& Exhibition Management", 5(2), s. 1-24.

GETZ D., 2008, Event tourism: Definition, evolution, and research, T, Tourism Management”, 29(3), s. $403-428$.

Goeldner CH.R., Ritchie J.R.B., 2003, Tourism: principles, practice, philosophies, John Wiley \& Sons, New York.

HAdZIK A., SzROMEK A.R., TOMIK R., 2012, Kibice międzynarodowych widowisk sportowych jako nowa kategoria konsumentów turystyki w Polsce, Prace Naukowe Uniwersytetu Ekonomicznego we Wrocławiu, 258, s. 68-78.

HERNÁNDEZ-MARTín R., 2007, Tourism Events: Impact on Imports, „International Journal of Event Management Research", 3(1), s. 15-28.

Hodur N.M., LeISTRITZ F.L., 2006, Estimating the Economic Impact of Event Tourism: A Review of Issues and Methods, "International Journal of Event and Festival Management", 8(4), s. 63-79. 
LiTvin S.W., 2013, Festivals and special events: making the investment, "International Journal of Culture, Tourism and Hospitality Research", 7(2), s. 184-187.

Morgan A., CONDliffe S., 2006, Measuring the Economic Impacts of Convention Centers and Event Tourism, „International Journal of Event and Festival Management”, 8(4), s. 81-100.

NAWROT Ł., ZMYŚLONY P., 2009, Międzynarodowa konkurencyjność regionu turystycznego. Od programowania rozwoju do zarządzania strategicznego, Proksenia, Kraków.

PAWLICZ A., 2012, Problemy szacowania wptywu niewielkich wydarzeń na lokalna gospodarkę na przykładzie festiwalu szachowego Konik Morski Rewala w latach 2009-2010, „Ekonomiczne Problemy Turystyki", 3(19), s. 124-137.

PIOTROWSKI P., 2012, Determinanty skuteczności wydarzeń marketingowych w tworzeniu turystycznego wizerunku miasta, „Studia Ekonomiczne”, 119, Uniwersytet Ekonomiczny w Katowicach, s. 153-161.

POON A., 1993, Tourism, Technology and Competitive Strategies, C.A.B International, Wallingford. PORTER M., 1990, The Competitive Advantage of Nations, The Macmillan Press, London.

RitchiE J.R.B., CROUCH G., 2000, The competitive destination: a sustainability perspective, "Tourism Management", 21.

STERKEN E., 2006, Growth Impact of Major Sporting Events, „European Sport Management Quarterly", 6(4), s. 375-389.

SWARBROOKE J., 2005, The development and management of visitor attractions, Elsevier Butterworth-Heinemann, Amsterdam.

VAnHove N., 2005, The Economics of Tourism Destinations, Elsevier Butterworth-Heinemann, Oxford.

WANAGOS M., 2010, Event marketing w aktywizacji obszarów turystycznych, "Acta Scientiarum Polonorum. Oeconomia", 4, s. 577-584.

WoOD E.H. 2005, Measuring the economic and social impacts of local authority events, "International Journal of Public Sector Management", 18(1), s. 37-53.

ZMYŚLONY P., PIECHOTA N., 2014, Znaczenie przemystu spotkań w kształtowaniu potencjału turystycznego miast, [w:] K. Celuch (red.), Zarzadzanie i organizacja przemystu spotkań w Polsce. Teoria i praktyka, Szkoła Główna Turystyki i Rekreacji w Warszawie, Warszawa, s. 103-117. 